\title{
THE ROLE OF LABOR UNION OF BPJS KETENAGAKERJAAN IN IMPROVING WELFARE AND CHANNELING THE ASPIRATION OF EMPLOYEES
}

\author{
Roadissa Habiba*, Hubeis Musa, Kuswanto Sadikin \\ School of Business, Bogor Agricultural University, Indonesia \\ *E-mail: habiba.roadissa@yahoo.com
}

\begin{abstract}
The aims of this research are analyzing the role of Labor Union of BPJS Ketenagakerjaan in improving the welfare of the employees, analyzing the role of Labor Union of BPJS Ketenagakerjaan in distributing the aspirations of the employees, analyzing the influence of Labor Union of BPJS Ketenagakerjaan in providing direct benefits to the employees and providing suggestions for Labor Union of BPJS Ketenagakerjaan in order to perform its functions optimally as the representative of the employees. The research method used was descriptive research and it applied qualitative approach. The research findings showed that the role of Labor Union of BPJS Ketenagakerjaan, according to the three sources, was good enough, both in terms of its role in improving the welfare of the employees and also its role in channeling the aspirations of the employees.
\end{abstract}

\section{KEY WORDS}

Aspiration, welfare, labor union, business.

Human Resources (HR) within an industry or company is a social creature in which they interconnect each other, even tend to form small groups. Within the group, there is a variety of interactions to the emergence of a sense of interconnectedness. Groups can be interpreted as a collection of two or more individuals who interact and maintain stable relationships, share common goals, and feel themselves to be a group (Greenberg and Baron, 2003: 273). In addition, Gibson et al. (2012: 230) defined a group as two or more of the workers who interact with each other in which the behavior and/ or performance of the members are affected by the behavior and/ or performance of the other members.

Company, as a gathering place of Human Resources (HR), shall provide freedom for its HR to group, organize or union in accordance with article $28 \mathrm{E}$ paragraph (3) the Amendment of the 1945 Constitution stating that everyone has the right to freedom of association, assembly and expressing opinion. Therefore, the company, as the shelter of human resources, shall implement the provision by giving freedom for the employees to be able to form a group or organization as a forum to gather and convey their aspirations; which is commonly referred to as trade union or labor union.

Labor union is defined by Handoko (1985: 158) as a workers' organization established to promote or express opinions, protect and improve through the collective activities, the social, economic and political interests of its members in which the dominant interests the union strives for are related to the economy.

The establishment of labor union in Indonesia dates from the 19th century, in which Netherland Indische Onderwys Genootschap (NIOG) or The Dutch Indies Teacher Worker Union was established in 1879, whose establishment was influenced by the growth of labor movement around 1860-1870 in the Netherlands. After the establishment of the NIOG, it led to the establishment of other labor union organizations, including the establishment of the Postal Worker Union (Pos Bond) in 1905, the Plantation Worker Union (Cultuur Bond) and the Sugar Worker Union (Zuiker Bond) in 1906, the Government Employee Worker Union in 1907, the Railway Workers Union (Spoor Bond) in 1913, and so forth up to this day.

Recognizing the rapid establishment of labor union and the importance of labor union rules, the Indonesian government ratified the results of the International Labor Organization (ILO) convention number 87 of 1948 on the Right for Association and Protection of Organizational Rights, which led to the growth of domestic unions. It is inseparable from the 
issuance of Presidential Decree No. 83 of 1998 which contains the ratification of Convention No. 87 on Freedom of Association and Protection of Organizational Rights and the issuance of Constitution number 21 of 2000 on Trade Union or Labor Union which regulate the definition, role, purpose, benefits and so forth.

Based on data compiled by the Ministry of Manpower in 2014, there were 6,808 unions with a total membership of 1,678,364 people in Indonesia.The existence of labor union within a company in Indonesia seems to have started to develop, in which various types of companies, both private companies, state-owned enterprises (BUMN), local-owned enterprises (BUMD) and state institutions have enough union organizations within their institutions. One of them is BPJS Ketenagakerjaan which is a government institution in the form of public legal entity, which participates in supporting the prevailing provisions by giving freedom to its employees to form a union. The labor union of BPJS Ketenagakerjaan is named by the Labor Union of BPJS Ketenagakerjaan (LU of BPJS Ketenagakerjaan) which is established on April 24, 1999. This LU of BPJS Ketenagakerjaan is a transformation of the Jamsostek Worker Union (SPJ) when the BPJS Ketenagakerjaan was still in the form of PT Jamsostek (Persero) as it is mentioned by Articles of Association (AD), chapter 2, article 2 on the timing of the Results of Extraordinary National General Assembly (MUNASLUB) of Jamsostek Worker Union in 2014.

At the initial observation, the employees felt that the active role of LU of BPJS Ketenagakerjaan is not optimal in carrying out its function. Various activities of LU of BPJS Ketenagakerjaan were rarely informed to the employees and the results of the activities and meetings conducted by LU of BPJS Ketenagakerjaan tended to be closed which only became the consumption of the board. The employees expected that LU of BPJS Ketenagakerjaan should be able to maximally run its role to fight for the welfare of employees and be able to publish all the activities they are conducting.

The aims of this research are (1) analyzing the role of Labor Union of BPJS Ketenagakerjaan (LU of BPJS Ketenagakerjaan) in improving the welfare of the employees, (2) analyzing the role of Labor Union of BPJS Ketenagakerjaan in distributing the aspirations of the employees, (3) analyzing the influence of Labor Union of BPJS Ketenagakerjaan in providing direct benefits to the employees and (4) providing suggestions for Labor Union of BPJS Ketenagakerjaan in order to perform its functions optimally as the representative of the employees.

\section{METHODS OF RESEARCH}

The research was conducted in the secretariat of LU of BPJS Ketenagakerjaan located in the headquarters building of BPJS Ketenagakerjaan on JI. Jend Gatot Subroto no. 79, South Jakarta. It was conduted on April 2017 until January 2018.

Data Processing and Data Analysis. The research method used in this research is descriptive research and is a qualitative research of phenomenology, that is qualitative research that examine phenomenon or what is apparent (Soewadji 2012: 62). Broadly speaking, the stages of the research consist of (1) reducing data, (2) combining data and (3) explaining the data.

Data Source. The primary data source used in this research consisted of several types of data sources. The first was the answer from the questionnaire to several examples of employees that fit the criteria set by the researchers.

Table 1 - The Code of Each Example

\begin{tabular}{clll}
\hline No & Elements & People (n) & Source Codes \\
\hline 1 & Industrial Relations Affairs of BPJS Ketenagakerjaan & 1 & Speaker 1 \\
2 & Member of Central Executive Board of LU of BPJS Ketenagakerjaan & 1 & Speaker 2 \\
3 & Member of Central Management Board of LU of BPJS Ketenagakerjaan & 1 & Speaker 3 \\
\hline Total & 3 & \\
\hline
\end{tabular}


The employee elements taken as resource persons in this research were categorized according to the characteristics of the sample set by the researcher, namely (1) the employee of the industrial relations affairs of BPJS Ketenagakerjaan, (2) the employee of the Central Executive Board of LU of BPJS Ketenagakerjaan, and (3) employee of the Central Management Board of LU of BPJS Ketenagakerjaan.

The examples of this research were presented by using snowball sampling technique.

\section{RESULTS AND DISCUSSION}

The Employment Agency for Social Security Employment (BPJS Ketenagakerjaan) is one of the public legal entities that provide social security for all workers in Indonesia. BPJS Ketenagakerjaan has four (4) social security programs, namely; employment injuries and work-related diseases, death benefit, old age benefit, and pension benefit. BPJS Ketenagakerjaan has a long history in its establishment, starting from Law No.33/ 1947 j.o. Law No.2/ 1951 concerning workplace accidents, Minister of Labor Regulation (PMP) No.48/ 1952 j.o. PMP No. 8/ 1956 on the arrangement of aid for the implementation of labor health, PMP No.15/ 1957 on the establishment of the Social Worker Foundation, PMP No.5/ 1964 on the establishment of the Social Security Fund (YDJS) Foundation and Law No.14/ 1969 on Manpower Principles. From these regulations, the government finally issued Government Regulation (PP) no. 33 of 1977 concerning the implementation of the social insurance program of labor (ASTEK), which requires every employer/ entrepreneur, both private and state-owned enterprises to protect their workers with ASTEK program, in which the PP is then refined by the issuance of PP. 34/1977 on the establishment of ASTEK organizers called Perum ASTEK.

A few years later, Perum ASTEK changed its name to PT Jamsostek (Persero) which its foundation is based on Law no. 3 of 1992 on Social Security of Labor (Jamsostek) and PP. 36 year 1995 which establish PT Jamsostek (Persero) as social security institution labor, which then run 4 protection programs consisting of; employment injury, death insurance, old age pension, and health care insurance.

Finally, the government issued Law no. 24 of 2011 on the Social Security Administrator which regulates the implementation of BPJS Kesehatan and BPJS Ketenagakerjaan. Based on the mandate, then PT Jamsostek (Persero) which previously in the form of state-owned enterprises (SOE) changed into a public legal entity with the name of BPJS Ketenagakerjaan.

The Profile of Labor Union of BPJS Ketenagakerjaan. Labor Union of BPJS Ketenagakerjaan is a place for workers who have a goal to convey their aspirations in defense of the rights and interests of the members and play an active role in improving the protection and welfare of BPJS Ketenagakerjaan workers. LU of BPJS Ketenagakerjaan is a transformation of Labor Union of Jamsostek which was established on 24 April 1999.

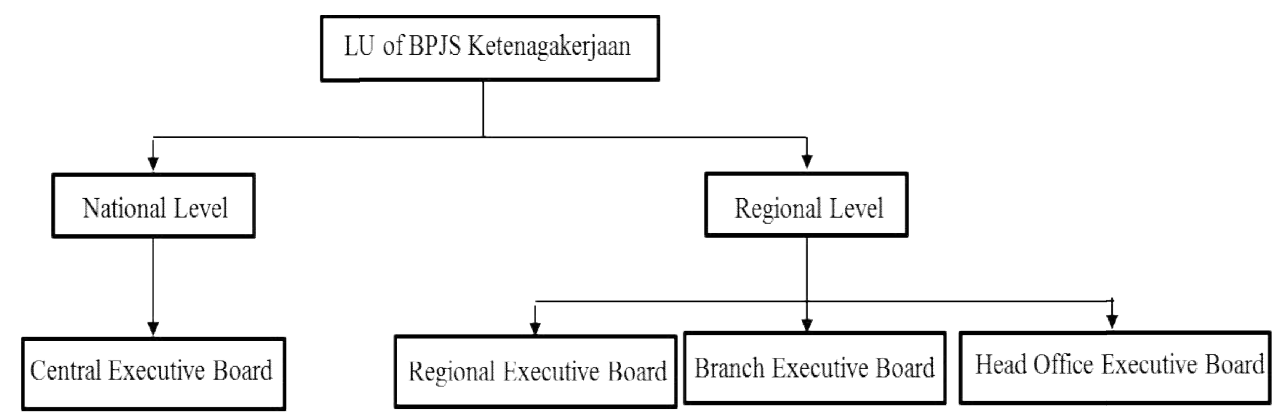

Figure 1 - LU of BPJS Ketenagakerjaan Organization Structure

LU of BPJS Ketenagakerjaan has the function to:

- Accommodate, channel, and fight for the aspirations of the members;

- Protect and defend the rights and interests of the members; 
- Encourage and mobilize members to improve professionalism, work productivity, and an active role in advancing the company;

- Become the partner of BPJS Ketenagakerjaan in improving protection and welfare for BPJS Ketenagakerjaan participants.

Furthermore, LU of BPJS Ketenagakerjaan has the aims to:

- Take an active role in realizing the vision and mission of BPJS Ketenagakerjaan;

- Maintain and protect the existence and reputation of BPJS Ketenagakerjaan;

- Channel aspirations, defend the rights and interests of the members and play an active role in improving the protection and the welfare of the workers.

The administration period of the LU of BPJS Ketenagakerjaan is stipulated in the Articles of Association (AD) in article 17 concerning the period of management, namely: (1) Central Leadership Board shall be elected every three (3) years through the national congress (MUNAS), (2) Regional Leadership board shall be elected every three (3) years through regional/ central congress (MUSWIL/ MUSKAPU), (3) the head of Regional/ Branch/ Division Leadership Board is elected every two (2) years through regional/ branch/ division congress, (4) the head of Central Leadership Board, Regional Leadership Board, Branch Leadership Board, and Division Leadership Board have the stewardship period maximum for two (2) periods respectively.

The role of LU of BPJS Ketenagakerjaan in Improving the Welfare of the Employee. After the research was conducted, the researchers obtained some points from the research findings: the three informants had enough understanding of the meaning of the union. The answer of each speaker entirely led to the same meaning; that is a group of employees formed to be a place for channeling the aspirations of the employees to the management of the company. The opinions of these three informants were in line with the definition of Labor Union under article 1 of Law no. 21 of 2000, "an organization formed from, by and for workers in and outside the company that is free, open, independent, democratic and responsible to defend, fight for and protect the rights and interests of the workers and laborers and improve the welfare of the workers/ laborers and their families".

Furthermore, from the interviews of the three informants, there were several different explanations related to the function of the union. For example, speaker 1 explained the function of the union as "the aspiration and coordination functions", then speaker 2 explained "the union as a strategic partner of management" and speaker 3 explained the function of union as "a bridge between workers and board members or directors".

Regarding to the characteristics of labor union, in accordance with Law no. 21 of 2000 , it explains the characteristics of labor union listed in articles 3, 5, 8, and 9 LU of BPJS Ketenagakerjaan as a union representing all employees in BPJS Ketenagakerjaan that meets the characteristics of those regulations as the following:

- Having free, open, independent, democratic, and responsible characteristics; LU of BPJS Ketenagakerjaan had prepared the functions and objectives of the organization which were clearly stated in the AD/ ART of LU of BPJS Ketenagakerjaan in which one of the points in the AD/ ART explained that LU of BPJS Ketenagakerjaan played a role in channeling the aspirations, defending the rights and interests of members and playing an active role in improving protection and the welfare of the workers.

- Trade union/ labor union shall be formed by at least 10 (ten) workers; LU of BPJS Ketenagakerjaan had a membership of 5,578 employees.

- The organizational level of trade union/ labor union, federation and confederation of trade union/ labor union shall be stipulated in its articles of association and/ or its household budget; LU of BPJS Ketenagakerjaan had already had its own AD/ ART which has been prepared in the National Congress (MUNAS).

- It is established on the free will of the workers without pressure or interference of the employers, governments, political parties, and any parties; LU of BPJS Ketenagakerjaan is established without pressure or interference from employers, governments, political parties, and any parties. LU of BPJS Ketenagakerjaan is purely established on the initiative of a group of employees who want to make a union. 
- It can be established based on business sector, occupation, and other forms that are in accordance with the will of the workers. LU of BPJS Ketenagakerjaan was established by a group of BPJS Ketenagakerjaan employees who work entirely for BPJS Ketenagakerjaan in social security.

Furthermore, in terms of the accountability report of the central management of LU of BPJS Ketenagakerjaan taken from 2013 to 2016, there were quite a lot of LU of BPJS Ketenagakerjaan activities that were carried out based on its function as a representative organization of all employees of BPJS Ketenagakerjaan, including:

- In 2013: Employee health treatment, retirement of PT Jamsostek employees and families after becoming BPJS Ketenagakerjaan (October 10, 2013), audiences and dialogue with BOD of BPJS Ketenagakerjaan related to the channeling of employee aspirations of PT Jamsostek (September 25, 2013), delivery of letters and aspirations to BOD of PT Jamsostek, application for reviewing the determination of grading and position level in redeployment process of employees and officials of PT Jamsostek (November 4, 2013).

- In 2014: Limited Discussion on Legal Study of Industrial Relations of BPJS Ketenagakerjaan: Collective Labor Agreement and Regulation of Directors (July 24, 2014), Industrial Relations and Labor Supervision (June 17, 2014), appeals for hearings to the Ministry of Manpower (June 17, 2014).

- In 2015: The Consideration of Employee and Family Health Insurance Service Program (July 3, 2015), Acknowledgment and Appreciation to the management of BPJS Ketenagakerjaan (December 8, 2015).

- In 2016: Commitment of the employees of BPJS Ketenagakerjaan and Aspiration Submission (January 27, 2016), Audience with Sri Sultan Hamengkubuwono X (March 1, 2016), Employee Support and Commitment of BPJS Ketenagakerjaan to the New Management (February 23, 2016), and Acknowledgments and Expectations of LU of BPJS Ketenagakerjaan (March 10, 2016).

All the activities were just some examples of activities that had been conducted in the period 2013-2016. By looking at those various activities that had been implemented by LU of BPJS Ketenagakerjaan, they had been able to perform its functions as a representative of all employees of BPJS Ketenagakerjaan one of which is to fight for the welfare of the employees to the management.

The Role of LU of BPJS Ketenagakerjaan in Channeling the Aspiration of the Employees. According to the informants, the LU of BPJS Ketenagakerjaan had not performed its function in channeling the aspirations of the employees maximally, as mentioned by the speaker 1 that the function of channeling the aspirations of the employees was not running maximally because there were some managers of LU of BPJS Ketenagakerjaan who tended to be passive to channelate employee aspirations in their own work units. However, it is different from what was mentioned by speaker 2 and speaker 3 . Both argue that the function of channeling aspirations had been running well enough so that the welfare of the employees was realized because of the struggle of LU of BPJS Ketenagakerjaan. The difference of opinion can be seen from the answer of speaker 1 who argued that the function of LU of BPJS Ketenagakerjaan in channeling employee aspiration had not been running maximally due to individual factor from the management of LU of BPJS Ketenagakerjaan who were less communicative.

Next, in channeling the aspirations of the employees, LU of BPJS Ketenagakerjaan had been using other media for its ease; one of them was through the questionnaire media on employee health insurance. The use of the questionnaire was one of the selected media to facilitate the data collection from thousands of employees spread across Indonesia. The results of the questionnaire could then be used as a suggestion for the management in managing the follow-up and improvement when there was a shortage in employee health insurance services. 
The meeting between the management of LU of BPJS Ketenagakerjaan with the manement is quite often. It can be seen from the activity report of LU of BPJS Ketenagakerjaan during 2013-2016 which noted that there were many meetings between LU of BPJS Ketenagakerjaan with the management as the following:

- In 2013: Employee health treatment, retirement of PT Jamsostek employees and families after becoming BPJS Ketenagakerjaan (October 10, 2013), audiences and dialogue with BOD of BPJS Ketenagakerjaan related to the channeling of employee aspirations of PT Jamsostek (September 25, 2013), delivery of letters and aspirations to BOD of PT Jamsostek, application for reviewing the determination of grading and position level in redeployment process of employees and officials of PT Jamsostek (November 4, 2013).

- In 2014: Limited Discussion on Legal Study of Industrial Relations of BPJS Ketenagakerjaan: Collective Labor Agreement and Regulation of Directors (July 24, 2014), Industrial Relations and Labor Supervision (June 17, 2014), appeals for hearings to the Ministry of Manpower (June 17, 2014).

- In 2015: The Consideration of Employee and Family Health Insurance Service Program (July 3, 2015), Acknowledgment and Appreciation to the management of BPJS Ketenagakerjaan (December 8, 2015).

- In 2016: Commitment of the employees of BPJS Ketenagakerjaan and Aspiration Submission (January 27, 2016), Audience with Sri Sultan Hamengkubuwono X (March 1, 2016), Employee Support and Commitment of BPJS Ketenagakerjaan to the New Management (February 23, 2016), and Acknowledgments and Expectations of LU of BPJS Ketenagakerjaan (March 10, 2016).

Some of these activities were part of activity report of LU of BPJS Ketenagakerjaan during 2013-2016. The researchers selected the above list of activities because the title and theme of the activities were considered to be in accordance with the activities of channeling the aspirations of the employees to the company management through LU of BPJS Ketenagakerjaan.

Benefits of LU of BPJS Ketenagakerjaan for the Employees. Speaker 1 looked at the benefits of LU of BPJS Ketenagakerjaan from the ease of aspirations delivery to the management. Then, according to speaker 2, related to the career of someone who had been working as the administrator of LU of BPJS Ketenagakerjaan, it tended to be easier in developing their career because there were considered to have leadership aspect from their experiences. And lastly, according to speaker 3, the benefits of becoming a member of LU of BPJS Ketenagakerjaan is to learn to organize, to know business process, and also to develop a network because it can add friends from different work units.

Suggestions for LU of BPJS Ketenagakerjaan in Running its Function as the Representative of the Employees. Based on the results of interviews with the three informants, there are several points of conclusions from each speaker in which according to the researcher, they are good suggestions for the improvement of LU of BPJS Ketenagakerjaan, as the following:

- The election of LU of BPJS Ketenagakerjaan head should be conducted by using evote mechanism so that all employees and members of LU of BPJS Ketenagakerjaan can participate in choosing the head of LU of BPJS Ketenagakerjaan. Generally, the election system was always conducted through congress meetings in which according to speaker 1 is less in accordance with developments of the current era that are demanding to use the technology. Speaker 1 proposed to use e-vote because the system is perceived to make it easier for the head candidate to conduct electronic campaigns and facilitate the employee as the owner of voting right to vote to the head candidate of their choices.

- The use of LU of BPJS Ketenagakerjaan website as LU of BPJS Ketenagakerjaan tool in channeling the aspirations of the employees, reporting activities that have been implemented by LU of BPJS Ketenagakerjaan, and facilitating e-vote as what have been discussed in the above paragraph. 
- Transparent use of LU of BPJS Ketenagakerjaan contributions that have been routinely paid monthly with pay cut mechanism. Speaker 1 suggested that the use of the contribution money might be transparently reported via LU of BPJS Ketenagakerjaan website so that all employees may know that the contributions are used appropriately and purposely.

- The competence improvement for all employees of BPJS Ketenagakerjaan. The competence improvement is intended for all employees of BPJS Ketenagakerjaan to be adaptive to the existing changes and threats.

- Speaker 2 expected that the management should be objective and ideal in listening to the demands of LU of BPJS Ketenagakerjaan. Thus, LU of BPJS Ketenagakerjaan can conduct audiences and establish a more intense communication. It indicates the communication between LU of BPJS Ketenagakerjaan and the management company has not run smoothly.

- LU of BPJS Ketenagakerjaan can be more independent. This suggestion is conveyed by speaker 3 that there was "like and dislike" in organizing in LU of BPJS Ketenagakerjaan. In addition, speaker 3 argued that there was a dislike attitude from the senior management to the new management. This likes and dislikes attitude might hamper organizational activities in LU of BPJS Ketenagakerjaan resulting in a less harmonious relationship and may cause obstacles in running the work program of LU of BPJS Ketenagakerjaan.

Managerial Implications. With this research, it is expected that the management of the company is able to establish a more harmonious industrial relations with the labor union, which is expected to:

- Able to accommodate the aspirations of employees submitted by the union;

- Able to bridging the needs of employees on the improvement of welfare that struggled by the labor union;

- Able to meet union demands when needs a meeting or mediation to the management;

- Management have to be more neutral and professional in giving employees flexibility in organizing in labor unions;

- Able to make the union as a partner in achieving the vision and mission of the company.

\section{CONCLUSION}

Based on the research findings that had been obtained by the researchers on the role of Labor Unions in improving the welfare and channeling of employee aspirations, the following conclusions can be drawn:

Based on the results of interviews to the data sources, all informant had enough understanding to the meaning and function of Labor Union of BPJS Ketenagakerjaan. All informants understood that the function of Labor Union of BPJS Ketenagakerjaan was sufficient and in accordance with the provisions of the applicable regulations, as is the function of Labor Union contained in Law no. 21 of 2000. In addition, still within the law, it regulates the characteristics of labor union. Based on Law no. 21 of 2000, the characteristics of Labor Union of BPJS Ketenagakerjaan have met the requirement of the applicable provisions.

Labor Union of BPJS Ketenagakerjaan has already had a systematic and clear AR/ ART related to the membership, activities, stewardship, reporting the results of activities and so forth. Within the AD/ ART, it is also clearly stated how the function, vision and mission of Labor Union of BPJS Ketenagakerjaan. The arrangement of AD/ ART is in accordance with the application of Law no. 21 of 2000 which authorizes each trade union or labor union to prepare its $A D / A R T$ respectively without any intervention.

The role of Labor Union of BPJS Ketenagakerjaan, in channeling of the aspirations of the employees to the management, is different according to the three informants, but the 
third opinion mentioned that the function of channeling aspirations is still not optimal. One of the causes why Labor Union of BPJS Ketenagakerjaan cannot perform its functions optimally is the boards or coordinators who are less active in playing their roles to collect the aspirations of the employees in their work units respectively.

In collecting the aspirations and asking the opinions of the employees relating with the welfare issue, Labor Union of BPJS Ketenagakerjaan had already released a questionnaire and distributed it to all employees. The questionnaire contained an evaluation of Nayaka; service provider of health insurance.

Meeting between Labor Union of BPJS Ketenagakerjaan and the management of the company is conducted regularly at least every 1 (one) month. The management gives an opportunity to Labor Union of BPJS Ketenagakerjaan to convey their aspirations and suggestions. In this meeting, both parties also communicate with each other in order to create a harmonious industrial relations climate.

Generally, two (2) people of three (3) informants quiet understand the benefits or advantages of being the official of labor union. Both informants underlined that the benefits of being the official of labor union is one form of employee participation in an organization in which the background of a person in the organization can be a consideration to improve his/her career. In addition to the consideration of the employee performance, the next point is to become the official of labor union in which it provide opportunities to learn, organize and broaden the network with the people. Furthermore, one speaker questioned the benefits of union contributions that have been routinely paid.

According to speaker 1, the activity report of LU of BPJS Ketenagakerjaan is not required to be reported to the management because the management of the company only provides the budget without giving any obligation to report the budget. However, in the point of view of LU of BPJS Ketenagakerjaan management, they have already seen either the activity report or financial report. Based on the explanation of the two informants, the financial and activity reports are well documented since the reporting process is conducted sequentially starting from the branch to regional leadership board until then the report is consolidated by the central leadership board.

There are several points that become suggestions from all informants for LU of BPJS Ketenagakerjaan including: the use of e-vote system mechanism in the election process of LU of BPJS Ketenagakerjaan Head, the improvement of competence of LU of BPJS Ketenagakerjaan employees in order to adapt to the existing changes and threats. In addition, the management should be more objective and ideal in listening to the demands from LU of BPJS Ketenagakerjaan and increase the intensity in implementing the audiences. Finally, LU of BPJS Ketenagakerjaan is expected to be more independent in carrying out the organization.

\section{REFERENCES}

1. Gibson, James L., John Ivancevich, James H, Donnelly, Jr. dan Robert Konopakse. 2012. Organizations. New York: McGraw-Hill.

2. Greenberg, Jerald dan Robert A. Baron. 2003. Behavior in Organizations. New Jersey: Pearson Education.

3. Handoko, T. Hani.1985. Manajemen Sumber Daya Manusia.Jogyakarta: BPFE Universitas Gadjah Mada.

4. International Labour Organization. 1999. Konvensi ILO yang Diratifikasi Indonesia. Staging.ilo.org [Internet].20 Oktober 1999[diunduh 11 Januari 2017]. Tersedia pada http://staging.ilo.org/public/libdoc/ilo/1999/99B09_193_i_e.pdf

5. Pemerintah Republik Indonesia.1969. Undang Undang Republik Indonesia Tahun 1945 Nomor 14 Tahun 1969.

6. Pemerintah Republik Indonesia.2000. Undang Undang Republik Indonesia Tahun 1945 Nomor 21 Tahun 2000.

7. Pemerintah Republik Indonesia.2000.Undang Undang Republik Indonesia Tahun 1945 Amandemen Kedua Pasal 28 Tahun 2000. 
8. Pemerintah Republik Indonesia.1947. Undang Undang Republik Indonesia Nomor 33 Tahun 1947.

9. Pemerintah Republik Indonesia.1998. Keputusan Presiden Republik Indonesia Nomor 83 Tahun 1998.

10. Serikat Pekerja BPJS Ketenagakerjaan. 2014. Hasil Musyawarah Nasional Luar Biasa (Munaslub) Serikat Pekerja Jamsostek (SPJ); Transformasi Serikat Pekerja Badan Penyelenggara Jaminan Sosial Ketenagakerjaan (SP BPJS-TK).

11. Soewadji,Jusuf.2012. Pengantar Metode Penelitian. Jakarta : Mitra Wacan Media.

12. Pemerintah Republik Indonesia.1952. Peraturan Menteri Perburuhan Republik Indonesia Tahun 1952 Nomor 48 Tahun 1952.

13. Pemerintah Republik Indonesia.1957. Peraturan Menteri Perburuhan Republik Indonesia Tahun 1957 Nomor 15 Tahun 1957.

14. Pemerintah Republik Indonesia.1957. Peraturan Menteri Perburuhan Republik Indonesia Tahun 1957 Nomor 15 Tahun 1957.

15. Pemerintah Republik Indonesia.1964. Peraturan Menteri Perburuhan Republik Indonesia Tahun 1964 Nomor 5 Tahun 1964.

16. Pemerintah Republik Indonesia.1977. Peraturan Pemerintah Republik Indonesia Tahun 1977 Nomor 33 Tahun 1977.

17. Pemerintah Republik Indonesia.1977. Peraturan Pemerintah Republik Indonesia Tahun 1977 Nomor 34 Tahun 1977.

18. Pemerintah Republik Indonesia.1992. Undang Undang Republik Indonesia Tahun 1992 Nomor 3 Tahun 1992.

19. Pemerintah Republik Indonesia.1995. Peraturan Pemerintah Republik Indonesia Tahun 1992 Nomor 36 Tahun 1992.

20. Pemerintah Republik Indonesia.2011. Undang Undang Republik Indonesia Tahun 2011 Nomor 24 Tahun 2011. 